\title{
Knowledge and integrated data management model for personalized intercropping in rubber plantation
}

\author{
Kornkanok Phoksawat ${ }^{1}$, Massudi Mahmuddin ${ }^{2}$ \\ ${ }^{1}$ Faculty of Management Technology, Rajamangala University of Technology Srivijaya, Thailand \\ ${ }^{1,2}$ School of Computing, Universiti Utara Malaysia, Malaysia
}

\begin{tabular}{l} 
Article Info \\
\hline Article history: \\
Received Nov 18, 2018 \\
Revised Apr 18, 2019 \\
Accepted Jun 12, 2019 \\
\hline
\end{tabular}

Keywords:

Integrated data management Intercropping

Knowledge-based

Multi-criteria decision making

Ontology for DSS

\begin{abstract}
Selection and allocation of space for intercropping in rubber plantations to maximize yield and minimum costs for individual farmers involves MultiCriteria Decision Making (MCDM) and several conditions. The problem is that the information is scattered in many related agencies, there are separate stores and some data is redundant. In addition, the format of the data varies depending on the purpose of the data. The knowledge of selecting plants to grow in the rubber plantation is the tacit knowledge acquired from the experience of successful farmers in rubber plantations and from agricultural experts. Therefore, this research involves an Integrated Ontology-based knowledge and Multi-Objective Optimization model for intercropping Decision Support Systems (DSS). This article presents the knowledge and integrated data management model for developing the Intercropping in Rubber Plantations Ontology by using the Triangulation in the method to verify the accuracy of the data and results. Moreover, propose ways to create recommendation rules that are easy to rule update and maintenance. Using an ontology for DSS helps to recommended plants according to the appropriate environment of the farmer area by rule-based inference to represent logical reasoning. It could also be applied to another domain that requires Intelligent DSS for MCDM.
\end{abstract}

Copyright (C) 2019 Institute of Advanced Engineering and Science. All rights reserved.

\section{Corresponding Author:}

Kornkanok Phoksawat,

Faculty of Management Technology,

Rajamangala University of Technology Srivijaya,

109Moo2 Tamyai, Thungsong, Nakhon Si Thammarat, 80110-Thailand.

Email: kornkanok.p@rmutsv.ac.th

\section{INTRODUCTION}

Soil and land resources are scarce resources thatcan not be regenerated, especially in Thailand. There is an area for agriculture of $35.7 \%$ of the total area of the country of which $79.10 \%$ is a monocultural system and $20.9 \%$ is a blend of agriculture [1]. Thailand is the world's second largest rubber plantation area and this major economic crop, along with other monocultures has suffered with uncertain low prices since 2014 causing a great decline in income in rubber farmers in the south and the Thailand economy [2]. Rubber is a key modern industrial raw material, not only used in tyres. This decline in rubber income led to the average debt of households in the south increasing, especially the $75 \%$ of all farmers who farm rubber [3] and were unable to pay their billsandmany farmers therefore decided to uproot their rubber trees and plant another crop.

Converting monoculture into a poly or intercropping system is a local wisdom or general way to solve problems for a particular area. [4] define Intercropping as a cropping system with, during a growing season, two or multiple crops planted in the same field and therefore a possible sustainable alternative for reducing the risk of insect attack and/ or plant pathogens and product price fluctuation [5]. 
Thailand government policy makers and policy implemented agencies have made a lot of attempts to support intercropping [6]. It also uses limited resources such as land and budget to get the most out of them.

The problem is the farmers lack knowledge for intercropping and do not know the production cost data of each plant [7]. The way to learn is from successful farmers, a learning center or a local philosopher [6]. The trial involved identifying what and how much to plant with the available resources of farmers and the investment costs and revenue estimates. From the above-mentioned problems, the researcher has the idea of developing a solution to the problem of planting space allocation. It includes recommending suitable plants with MCDM. There are several purposesin selecting the right plants; use the knowledge-base to introduce the list of plants and allocate each area to suit the area conditions and individual farmer conditions together with the multi-objective optimization model for resource allocation. That is, farmers have the highest annual income and the lowest cost, according to the principle of intercropping.

According to studies, it has been found that information to support the decision forintercropping in rubber plants is scattered in many agencies with the mission of promoting the cultivation of crops and Knowledge Management (KM). It is the transfer of knowledge from the experts through study visits and publishing the documents of each agency to manage knowledge according to the principle of knowledge engineering that contains techniques and tools to create knowledge. It is an information technology system that behaves in a human-like way to identify a solution or decision and determine the reason for information and decision-making information. There are many ways to create knowledge-based methods such as understanding and solving new problems using Case-Based Reasoning (CBR) from prior experience of similar cases [8], and Ontologies [9].

Ontologies are one of the basic concepts of the Semantic Web Technology [10] which is an extension of the current web in which information is given meaning in a well-defined machine readable way to assist cooperative working between people and computers [10], and particularly used in the Knowledge Engineering field [11]. An ontology is a presentation of vocabulary that represents knowledge or concepts. This is a set of information in the form of concepts and relationships that represent data and data structures. Ontologies rather than databases support the relationship between data because ontologies can determine the relationship between concepts. Ontologies focus on the meaning of the information that is used for sharing and mutual understanding between people or software. The primary objective of ontologies is to determine knowledge and proportionated domain model from a variety of sources [12]. Therefore, the ontology is also used in knowledge management. It helps to find that knowledge easily. It can be checked and results are more accurateby creating ontologies and rules in order to infer knowledge and reasoning [13]. In addition, the ontology is also used to increase the efficiency ofrecommender system. For example, it helps computers in predicting users' implicit knowledge. Recommender systems use Ontologies to help become a multi-class environment [14], and used for Intelligent Decision Support Systems (IDSS) [15]. Consequently, an intercropping ontology was designed and developed for DSS to recommend a plant for intercrop in rubber plantation that can be reused and share the knowledge and logic reasoning to be used in the introduction of plants suitable for individual farmers.

The ontology development life cycle by [16] involves seven steps including: 1) "Determine the Domain and Scope of the Ontology, 2) Consider Reusing Existing Ontologies, 3) Enumerate Terms in the Ontology, 4) Define Classes and the Class Hierarchy, 5) Define the Properties of Classes-slots, 6) Define the Facets of the Slots, and 7) Create Instances". However, in step 2 of the ontology development which is to consider the use of existing ontologies. From the literature review, it appears that there is a lack of an ontology for intercropping in a rubber plantation. Ontology development should be based on application objectives, data characteristic context, rules, and future reuse feasibility [17-20].

Therefore, this paper proposed a Knowledge and Integrated Data Management model for development ontology for recommend personalized intercropping in rubber plantation by using ontology as the knowledge acquisition to develop the scope of knowledge and categorize knowledge into groups in order to form knowledge modeling and an integrated dataset with rule-based which is necessary to make the decision to plant rubber trees based on some individual factors. The rest of this paper is organized in the following way: section 1 provides a background of the study; section 2 is; research methodology; section 3 represents the research results, and the last section is the conclusion and future work.

\section{RESEARCH METHOD}

The DSS for optimization of rubber plantation planning has two steps: 1) Recommending the right intercrop and 2) the allocation of growing space to achieve two objectives which are the maximum earning with the minimum total cost under the resources and capital of the farmers. Therefore, the DSS for intercropping is an integrated method which works together in two steps as shown in Figure 1. 


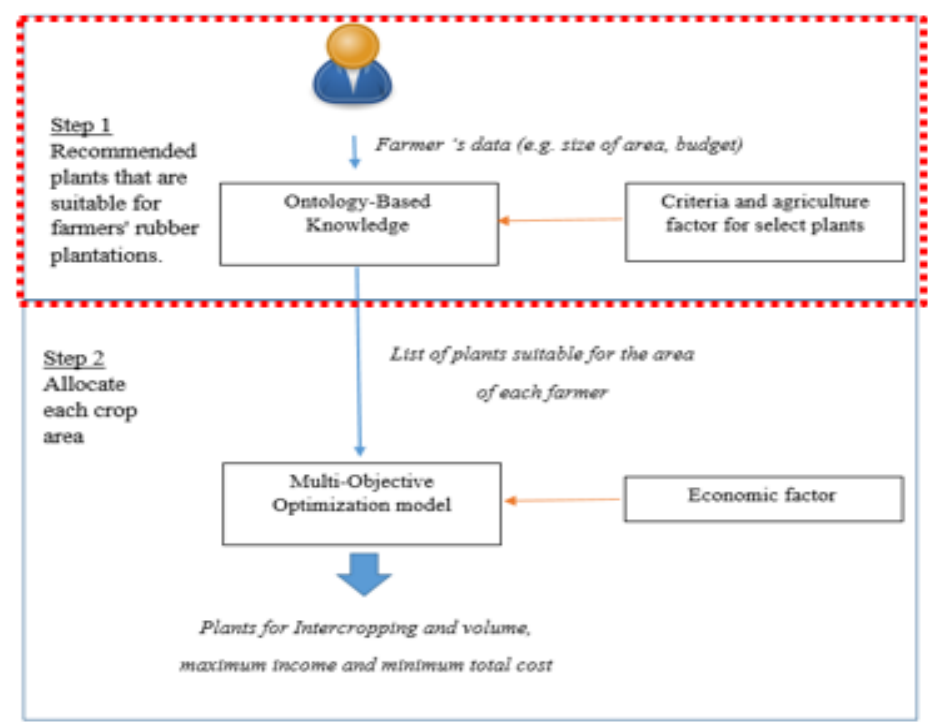

Figure 1. Research conceptual framework of ontology and optimization model for DSS-intercropping

The first step of the research called personalized intercropping recommender moduleis a part of development Intercropping Ontology for recommend the plant for intercropping in the farmer's area. The knowledge-based partuses the process of knowledge engineering with ontology to obtain a rubber plantation model and to develop an Intercropping Ontology and logical approach that will lead to a more intelligent DSS which is mixed with a Multi-Objective Optimization model (MOO) part. The second step will help to calculate and allocate each crop area to give maximum yield and the minimum cost so the system will help farmers or users make decisions as a guideline or primary recommendations before making a decision on plantation operation as indicated by soil, time, season, area, cost, and market price or other critical parameters.

In this article present only step 1 of the research. The research process in Step 1 consist of 5 processes as shown in Figure 2 including; 1) Setting objective and scope of the top level domain classes of Ontology, 2) knowledge and integrated data management process, 3) Ontology construction by using ontology editor, 4) Database to ontology mapping, and 5) Evaluation.

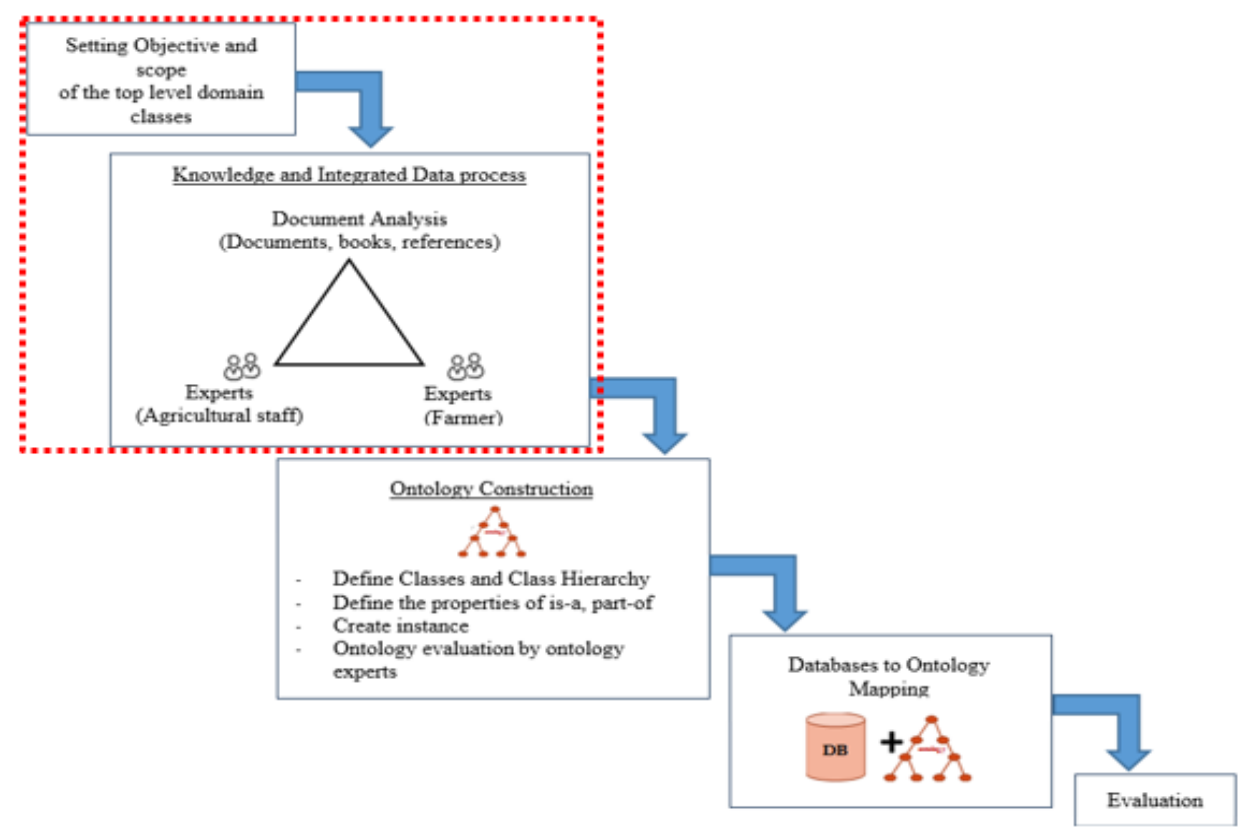

Figure 2. Personalized intercropping ontology development for DSS 
However, this article presents the processes 1 and 2 which provide the knowledge modeling, soil and plant dataset, and rules before construct Intercropping Ontology by using ontology editor.

\subsection{Setting scope and objective to create the intercropping ontology}

This research aims to create an ontology as the Knowledge-based in the DSS for the allocation of rubber plantation areas for many purposes. The scope of the study is to provide a recommender part that recommends a suitable plant to be cultivated during the short-term returns within 1 year of cultivation. The farmers can earn income during the year and it must be a plant that has been planted as intercropping before, especially in the list of recommendations of the Department of Agricultural Extension.

\subsection{Inegrated knowledge and data management}

Knowledge from related sources regarding the intercropping needs to be integrated in order to facilitate the management of decision process. This required data to be collected from various sources. The integration of knowledge and data is a triangulation method [21]. Therefore, the data collection is based on three sources: 1) Secondary data, analysis of documents obtained from research or public information. 2) Four government official organizations staff including, one Land Surveyor Expert, one expert from Rubber Authority of Thailand, and two experts from Provincial Agriculture Office, 3) three expert farmers who have succeeded at intercropping in rubber plantations. And using 3 different methods: Document Analysis, Interview, and Focus Group.

a. Document analysis

Documentary analysis is intended to verify the knowledge from secondary data e.g. research papers and data publication of existing intercropping in rubber plantations of the Ministry of Agriculture and Cooperatives. There is a mission to promote rubber plantations including: Department of Agricultural Extention, Land Development Regional 11 Office, Provincial Agriculture Office, and Land Development Office as shown in Table 1.

Table 1. Summarized sources of data and knowledge to support decision making for intercropping

\begin{tabular}{ll}
\hline \multicolumn{1}{c}{ Organization } & \multicolumn{1}{c}{ Type of information } \\
\hline Department of Agricultural Extention & - Knowledge and media for cropping \\
Office of Agricultural Economic & - Sale Price per Kg. (THB) \\
& - Cost per rai (THB). It is the area measurement unit of Thailand by 1 rai \\
& $=1,600$ square meters \\
& - Productivity per rai (Kg.) \\
Rubber Authority of Thailand & - Principle of intercropping in rubber plantation \\
Land Development Regional 11 Office & - Soil information each sub-district \\
Provincial Agriculture Office & Advising agriculture in each province for intercropping \\
\hline
\end{tabular}

\section{b. Expert interview}

The experts were selected from three experts at intercropping in rubber plantations and two academics from government agencies who are responsible for promoting the rubber plantation, the staff of the Rubber of Thailand, and a soil expert from the Land Development Department. After that the content was analysed.

Then the scope of knowledge in each of the concepts and data attributes, data relationship and knowledge modeling were sketched out. After that, dataset was prepared for processing. Due to the raw data obtained from the various sources, there must be a process of data cleaning and data transformation to a format that can be used.

c. Validate the results and rule using focus group by expert farmers in the final stages

\section{RESEARCH RESULTS}

The study found that the criteria for selection of plants for rubber plantation of individual farmers were in two groups; 1) Agricultural criteria, including the planting period of the rubber trees, water and soil types, and plant diseases found that pest and disease damage in intercropping is less than monocropping [22]. Expert farmers insist that integrated cropping will help reduce plant disease. The plant disease is not a factor for the decision to plant rubber trees this time; 2) Economic criteria include cost of growing each plant and yield, the problem of rubber plantation selection for small farmers, and recommending the plants suitable for the area and constraints of the rubber farmer. Even though the plants have high returns, but it is not suitable for the condition of the rubber plantation and not suitable for the plant to follow the principles of rubber plantation. It should not be planted because it may interfere with the growth of 
the tree, and the output is not as desired. Hence, the importance of the area of the previous rubber plantation. Then, considering the economic factors in the allocation of planting areas in accordance with the principle of planting mixed plants to plant two or more. The Multi-Objective Optimization model is used to achieve maximum revenue objectives, with the minimum cost under the budget constraints of the farmers. Figure 3 shows the concept and Criteria for Decision Making to Intercropping in Rubber Plantation Domain.

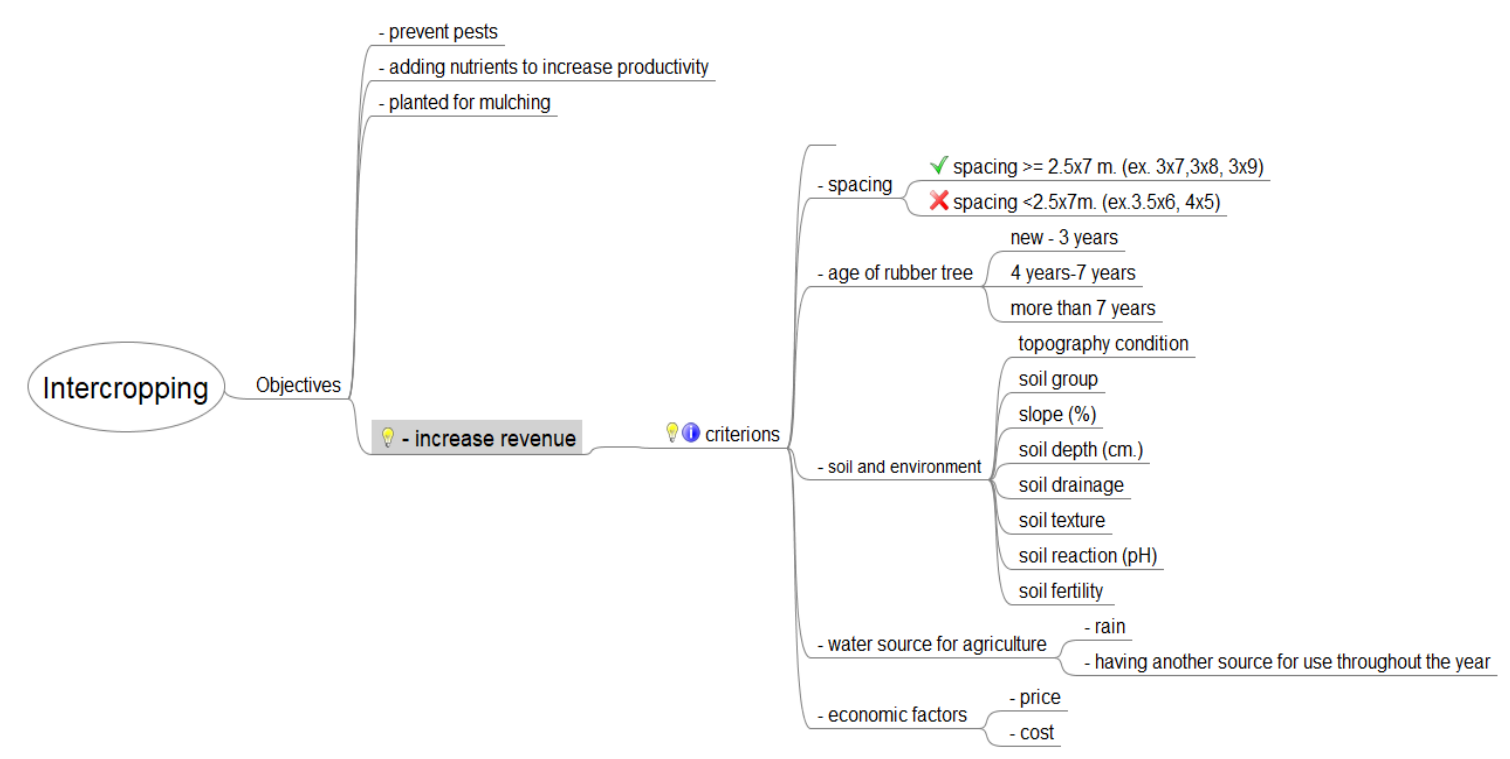

Figure 3. Concept and criteria for decision making to intercropping in rubber plantation domain

a. Age of rubber tree

The age of the rubber is related to sunlight to reach the planting area, when the tree is about 4 years old. The branches and leaves let much less sunlight reachthe ground. It also has a relationship with the planting period, so the age of the rubber tree is a guideline for introducing the plant.

b. Spacing between rows

The Rrubber Authority of Thailand has introduced the rubber planting spacing between plots. There are many choices such as: $2 \times 5$ meters $(\mathrm{m}), 3 \times 6 \mathrm{~m}, 3 \times 7 \mathrm{~m}, 3 \times 8 \mathrm{~m}$, and $3 \times 9 \mathrm{~m}$. If the farmers' areas are less than $3 \times 7 \mathrm{~m}$ e.g. $2 \times 5 \mathrm{~m}, 3 \times 6 \mathrm{~m}$, or $4 \times 5 \mathrm{~m}$, it is not suitable for intercropping. The experts recommend that the crop must be planted at least $1 \mathrm{~m}$ apart from the row of trees plus half of the distance between rows of the plant to avoid shading and spoiling rubber tree fertilizers. Thus, the distance between the rubber plantings is $3 \times 7 \mathrm{~m}$ or more. However, there are some plants that can be grown, such as upland rice, or beans.

c. Water source for agriculture

Water sources for agriculture are the factors used to determine the appropriate crop. Each plant requires different amounts of water. If farmers have access to agricultural water throughout the year, no rain is required. This factor affects the selection of plants suitable for this constraint of farmers. If there is sufficient water supply to agriculture, it will be possible to select some vegetable and fruit crops such as cucumbers, paprikas, etc. But if there is no source of water only rain water in the season, it should be used to grow crops, such as upland rice, corn and sugarcane, etc.

d. Soil group

Thailand has 62 clay soil series [23]. This group of soils is a unit of the land plan developed by the Department of Land Development by combining soil group with properties and potential for cultivation including the same management of the soil for the sake of advice, soil monitoring, land use, and appropriate soil management for farmers and people who are interested. In considering the suitability of soils used in agriculture, consider the following as shown in Table 2 topography condition, soil slope (\%), depth (cm), soil drainage, texture, that have 2 level includingtop and sub-soil, soil reactin $(\mathrm{pH})$, and fertility.

The Land Development Department has mapped the soil groups for growing the province's economic crops throughout the country, with a ratio 1: 50000. Land development has continued to the present. For example, according to the land survey of the Land Development Department, it was found 
that in Nakhon Si Thammarat province, a total of 41 different soil groups could be classified. Moreover, there are also additional slope assignments for each soil group by defining the end of the soil group numbers;

Slope level A: soil_group has a 0-2\% slope gradient (but slope sign A is not show after the soil_group).

Slope level B: soil_group has a steep slope of 2-5\%.

Slope level C: soil_group with slope of 6-12\%.

Slope level D: soil_group with slope more than $12 \%$.

Table 2. Sample of type of soil and it's properties

\begin{tabular}{|c|c|c|c|c|c|c|c|c|c|c|c|c|}
\hline 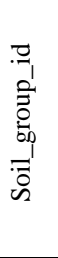 & 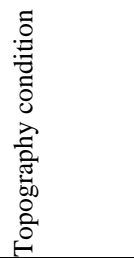 & $\begin{array}{l}\frac{a}{2} \\
\frac{0}{0}\end{array}$ & 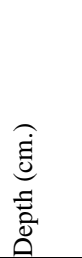 & 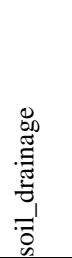 & 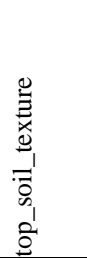 & 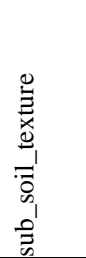 & $\begin{array}{l} \pm \\
0 \\
0 \\
0 \\
0 \\
0 \\
0 \\
0 \\
0 \\
0\end{array}$ & $\begin{array}{l}\bar{\Xi} \\
0 \\
0 \\
0 \\
=\overline{0} \\
0 \\
0 \\
0 \\
0 \\
0\end{array}$ & 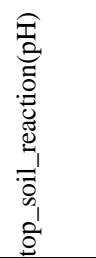 & 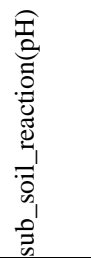 & 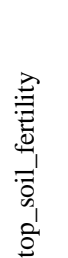 & 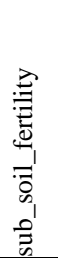 \\
\hline 26 & $\begin{array}{l}\text { the area of } \\
\text { high } \\
\text { smooth } \\
\text { ground or } \\
\text { quite } \\
\text { smooth }\end{array}$ & $0-2$ & $>150$ & good & $\begin{array}{l}\text { Clay } \\
\text { loam }\end{array}$ & clay & brown & $\begin{array}{l}\text { Brown or } \\
\text { brown } \\
\text { and } \\
\text { yellow }\end{array}$ & $5.0-5.5$ & $4.5-5.5$ & Low & Low \\
\hline 34B & $\begin{array}{l}\text { the area of } \\
\text { high } \\
\text { ground, } \\
\text { wave, little } \\
\text { wave }\end{array}$ & $2-5$ & $>150$ & good & $\begin{array}{l}\text { sandy } \\
\text { loam }\end{array}$ & $\begin{array}{l}\text { Mold, } \\
\text { clay } \\
\text { sand }\end{array}$ & $\begin{array}{l}\text { Brown } \\
\text { or } \\
\text { brown } \\
\text { and } \\
\text { yellow }\end{array}$ & $\begin{array}{l}\text { Brown or } \\
\text { brown } \\
\text { and } \\
\text { yellowor } \\
\text { red }\end{array}$ & $5.0-5.5$ & $4.5-5.5$ & Low & Low \\
\hline $45 \mathrm{C}$ & $\begin{array}{l}\text { the area of } \\
\text { high } \\
\text { ground, } \\
\text { wave }\end{array}$ & $5-12$ & $\begin{array}{l}<50 \\
\text { clast } \\
\text { level } \\
\text { or } \\
\text { gravel }\end{array}$ & good & $\begin{array}{l}\text { Clay } \\
\text { loam, } \\
\text { sandy } \\
\text { loam } \\
\text { with } \\
\text { gravel }\end{array}$ & $\begin{array}{l}\text { Clay } \\
\text { gravel } \\
\text { or } \\
\text { clay } \\
\text { layer } \\
\text { found } \\
\text { in the } \\
\text { soil }\end{array}$ & $\begin{array}{l}\text { Brown } \\
\text { or } \\
\text { brown } \\
\text { and } \\
\text { red }\end{array}$ & $\begin{array}{l}\text { Yellow, } \\
\text { red, or } \\
\text { red and } \\
\text { yellow }\end{array}$ & $5.0-6.0$ & $4.5-5.5$ & Low & Low \\
\hline
\end{tabular}

It gives the suitability for growing plants as shown in Table 3. This set of information will help to identify what kind of soil the farmer's area is in. The soil suitability classification is based on the soil suitability guidelines for economic crops of Thailand in 2010, by the Division of Survey and Classification of Soil. The Department of Land Development identified into 3 planting classificationsof soil : 1=well suited, $2=$ poorly suited, and $3=$ unsuitable [23].

Table 3. Examples of some plants that suitable of some soil group in Bang Khan district, Nakhon Si Thammarat

\begin{tabular}{ccccccccc}
\hline Sub-district & $\begin{array}{c}\text { Soil } \\
\text { group }\end{array}$ & $\begin{array}{c}\text { Rubber } \\
\text { tree }\end{array}$ & $\begin{array}{c}\text { Robusta } \\
\text { coffee }\end{array}$ & Pineapple & Guava & Banana & $\begin{array}{c}\text { Upland } \\
\text { rice }\end{array}$ & Nut \\
\hline Ban Nikhom & 26 & 1 & 1 & 1 & 1 & 1 & 1 & 1 \\
Bang khan & $34 \mathrm{~B}$ & 1 & 1 & 1 & 1 & 1 & 1 & 1 \\
Ban Lamnao & $45 \mathrm{C}$ & 2 & 2 & 2 & 2 & 1 & 2 & 2 \\
Bang Lhan & 62 & 3 & 3 & 3 & 3 & 3 & 3 & 3 \\
\hline
\end{tabular}

The type of soil suitable for each plant in the district rubber plantation is known. In Ban Nikhom sub-district, Bang Khan district, the soil group 26 is a fine soil of the deep clay group formed by sediment found in the rainfed southern part of Thailand. It is appropriate for vegetables,fruits, rubber trees, and some crops. The soil group 45C in Ban Lamnao sub-district is unsuitable for vegetable cultivation but suitable for banana planting. However, the soil set 62 in Bang Lhan subdistrict is not suitable for growing crops because it has a slope of over $35 \%$ with some rocky areas which may cause soil erosion. Therefore, in this research, the suitability of each type of soil is only appropriate (appropriate level=1) for each plant. 


\section{e. Economic factor}

The price to be calculated in the optimization model is the average price in the past year collected from: The Department of Internal Trade, the Office of Agricultural Economics, and the private centre for fruit and vegetable markets. The data will be prepared in the database but will not be taken into account at this stage because the main purpose of this step is to know what plants are suitable for the area of farmers. Once the list of plants has been obtained, then those names will be used as decision variables in the next stage in the Multi-Objective Optimization model. It will be presented in future work.

Plants for intercropping data have received information from many agencies of the Ministry of Agriculture and Cooperatives Thailand. Samples selected from plants were tested in rubber plantations in each area of Thailand and which are included in the publication. The choice of small para-rubber farmers as supplemented revenue at the Department of Agricultural Extension Ministry of Agriculture and Cooperatives which consists of 6 crop types (vegetables, herbs, fruits, perennials, ornamental plants, crops) and 30 items that can harvest within 1 year [24]. It displays plant information such as crop type, environment condition, planting time till harvesting, output ( $\mathrm{kg}$ per rai), cost (seed cost, soil preparation cost and the cost of cultivation e.g. maintenance costs) As shown in Figure 4. The price of the product uses the average price during the seasonal output in the previous year. Since each unit does not collect the price of agricultural products of all kinds it is collected from 3 organizations: The Department of Internal Trade, the Office of Agricultural Economics, and the private sector central markets for fruits and vegetables. For example, galingale is suitable for rubber plantations that are less than 7 years old. Planting time is about 210 days. Production is $2,000 \mathrm{~kg}$ per rai, and cost of planting 18,070 THB and maintrain cost 1,300 THB per rai etc.

\begin{tabular}{|c|c|c|c|c|c|c|c|c|c|c|}
\hline Order & Name & Type & Water & Age & Distance & Time(days) & Cost & Maintrain cost & Output (kg) & Price $/ \mathrm{kg}$ \\
\hline 1 & Galingale & Vetgetable & no & new-7 & $>=3 \times 7 \mathrm{~m}$ & 210 & 18,070 & 1,300 & 2,000 & 48 \\
\hline 2 & Pumpkin & Vetgetable & yes & new-3 & $>=3 \times 7 \mathrm{~m}$ & 120 & 6,140 & 5,800 & 4,000 & 10 \\
\hline 3 & Tomato & Vetgetable & yes & new-3 & $>=3 \times 7 \mathrm{~m}$ & 90 & 8,470 & 3,240 & 4,000 & 24 \\
\hline 4 & Cucrcuma & Herbs & no & new-7 & $>=3 \times 7 \mathrm{~m}$ & 210 & 21,000 & 6,000 & 2,800 & 40 \\
\hline 5 & Long Pepper & Herbs & yes & new-3 & $>=3 \times 7 \mathrm{~m}$ & 180 & 89,000 & 6,000 & 600 & 200 \\
\hline 6 & Kariyat & Herbs & yes & new-3 & $>=3 \times 7 \mathrm{~m}$ & 120 & 7,300 & 700 & 1,000 & 80 \\
\hline 7 & Golden banana & Fruit_crop & yes & new-3 & $>=3 \times 7 \mathrm{~m}$ & 300 & 7,000 & 4,340 & 760 & 25 \\
\hline 8 & Gros Michel banana & Fruit_crop & yes & new-3 & $>=3 \times 7 \mathrm{~m}$ & 300 & 18,780 & 6,600 & 750 & 60 \\
\hline 9 & Guava & Fruit_crop & yes & new & $>=3 \times 7 \mathrm{~m}$ & 240 & 28,000 & 10,000 & 800 & 39 \\
\hline 10 & Papaya & Fruit_crop & yes & new & $>=3 \times 7 \mathrm{~m}$ & 120 & 20,500 & 7,500 & 6,000 & 32 \\
\hline 11 & Lemon grass & Vetgetable & no & new-3 & $>=3 \times 7 \mathrm{~m}$ & 90 & 2,580 & & 2,000 & 40 \\
\hline 12 & Passion fruit & Fruit_crop & yes & new & $>=3 \times 7 \mathrm{~m}$ & 210 & 9,800 & 4,000 & 3,000 & 65 \\
\hline 13 & Sweet Bamboo & Perennials plants & no & $>=4$ & $>=3 \times 7 \mathrm{~m}$ & 240 & 8,000 & 2,000 & 1,800 & 40 \\
\hline 14 & Marigold & Ornamental plants & yes & new-3 & $>=3 \times 7 \mathrm{~m}$ & 60 & 3,500 & 500 & 20,000 & 1 \\
\hline 15 & Torch Ginger & Ornamental plants & yes & $>7$ & $>=3 \times 7 \mathrm{~m}$ & 360 & 36,200 & 4,300 & 32,000 & 8 \\
\hline 16 & Buterfly plam & Ornamental plants & yes & $>7$ & $>=3 \times 7 \mathrm{~m}$ & 300 & 8,000 & 4,000 & 8,000 & 2 \\
\hline 17 & Maize & field_crops & no & new-3 & $>=3 \times 7 \mathrm{~m}$ & 120 & 3,200 & 1,980 & 900 & 10 \\
\hline 18 & Sweet Corn & field_crops & no & new-3 & $>=3 \times 7 \mathrm{~m}$ & 60 & 4,200 & 1,200 & 1,800 & 15 \\
\hline 19 & Peanut & field_crops & no & new-3 & $<3 \times 7 \mathrm{~m}$ & 120 & 3,820 & 2,900 & 260 & 35 \\
\hline 20 & Bambarra Groundnut & field_crops & no & new-3 & $<3 \times 7 \mathrm{~m}$ & 120 & 600 & 125 & 400 & 20 \\
\hline 21 & Cane & field_crops & no & new-3 & $>=3 \times 7 \mathrm{~m}$ & 240 & 12,110 & 1,030 & 5,000 & 10 \\
\hline 22 & Cucumber & Vetgetable & yes & new-2 & $>=3 \times 7 \mathrm{~m}$ & 90 & 17,000 & 8,530 & 5,000 & 18 \\
\hline 23 & Upland rice & field_crops & no & new-3 & $<3 \times 7 \mathrm{~m}$ & 125 & 850 & 300 & 400 & 60 \\
\hline 24 & Purple guinea grass & field_crops & yes & new-3 & $>=3 \times 7 \mathrm{~m}$ & 60 & 2,000 & 300 & 5,000 & 3 \\
\hline 25 & Vegetable Fern & Vetgetable & yes & $>7$ & $>=3 \times 7 \mathrm{~m}$ & 180 & 20,850 & 2,000 & 1,800 & 28 \\
\hline 26 & Leaves Melinjo & Vetgetable & no & $>=4$ & $>=3 \times 7 \mathrm{~m}$ & 360 & 5,590 & 850 & 400 & 30 \\
\hline 27 & Melientha Suavis & Vetgetable & yes & new-7 & $>=3 \times 7 \mathrm{~m}$ & 90 & 48,000 & & 1,500 & 70 \\
\hline 28 & Melientha Suavis Pie & Vetgetable & no & new-7 & $>=3 \times 7 \mathrm{~m}$ & 360 & 6,750 & 2,000 & 1,200 & 70 \\
\hline 29 & Chilli & Vetgetable & yes & new-3 & $>=3 \times 7 \mathrm{~m}$ & 90 & 11,200 & 1,500 & 1,250 & 113 \\
\hline 30 & White Chilli & Vetgetable & yes & new-3 & $>=3 \times 7 \mathrm{~m}$ & 90 & 11,500 & 1,500 & 1,280 & 110 \\
\hline
\end{tabular}

Figure 4. Plants for intercropping data

Another interesting aspect of Ontology is that can use inference through the rules that created so that the ontology that is designed and built already exists. It can learn new knowledge always get through the rules. The rule language used with the ontology called Semantic Web Rule Language (SWRL) [25]. A recommendation rule is usually done using a rule editor. However, not easy to create bulk rules creation and often have complicated procedures for managing and updating the rule update and maintenance. 
Therefore, in this step the rule is in the form of a Microsoft Excel spreadsheet which defines the format as a decision table. It's easy to create a lot of rules and easily modify the rule base. Moreover, it is easy to use to check the accuracy of the results from the rules created. The results from the rule-base can be compared with the results of the experts as well by filtering data contained in the menu of MS Excel. Creating a table for the introduction criteria is divided into 2 parts: part 1 is each plant and part 2 is the name of evaluation criteria. It will have the range values of criteria in each criteria including:

- The spacing criteria have 2 range values: distance $>=3 \times 7 \mathrm{~m}$ is "large" and distance $<3 \times 7 \mathrm{~m}$ is "small".

- Age criteria of rubber trees will be divided into 5 age ranges. Therefore, there are 5 range values, consisting of "0", "0-3", "> 4", "0-7", and "> 7".

- Water source criteria for agriculture means 'Do farmers have water sources used throughout the year?' The criteria will be set to only 2 values: "yes" and "no".

- Soil is suitability for growing each type of intercropping. The possible sub-criteria are 41 different soil groups.

However, the name of the criteria must be the merge cells to cover the values of all related criteria. For example, galangal, is recommended to plant in the garden area with a distance of $3 \times 7$ meters upand rubber age from 4 years. It is because the galangal likes sunshine and has no need to water all year round, just enough in seasonal rainfall. It is suitable for soil group 26, 26gm, 26B, 26C, 32, 34 etc. The $x$ is put in the value of the rule criteria as shown in Figure 5.

The plant for intercropping used in this study has 30 species with 554 recommendation rules are based on the distance between rows, the age of rubber tree, agricultural water source, and soil group mapping. This recommendation rule has passed the rule inspection in the introduction by expert farmers in rubber plantations for the accuracy of the recommendation results before being used in the next step of the research.

\begin{tabular}{|c|c|c|c|c|c|c|c|c|c|c|c|c|c|c|c|c|c|c|c|c|c|c|c|c|}
\hline \multirow[b]{2}{*}{ plant } & \multicolumn{2}{|c|}{ distance } & \multicolumn{5}{|c|}{ rubber_age (year) } & \multicolumn{2}{|c|}{ water } & \multicolumn{15}{|c|}{ soil_group suitable for planting } \\
\hline & large & small & $\mathbf{0}$ & $0-3$ & $0-7$ & $>4$ & $>7$ & yes & no & 26 & $26 \mathrm{gm}$ & $26 \mathrm{~B}$ & $26 \mathrm{C}$ & 26D & 32 & $32 \mathrm{gm}$ & 34 & 34gm & 34B & $34 \mathrm{C}$ & 34D & 39 & 39B & 39C \\
\hline galangal & $\mathrm{x}$ & & & & & $\mathrm{x}$ & & & $\mathrm{x}$ & & $\mathrm{x}$ & & & & & & & & & & & & & \\
\hline galangal & $\mathrm{x}$ & & & & & $\mathrm{x}$ & & & $\mathrm{x}$ & & & & $\mathrm{x}$ & & & & & & & & & & & \\
\hline galangal & $\mathrm{x}$ & & & & & $\mathrm{x}$ & & & $\mathrm{x}$ & & & & & & $\mathrm{x}$ & & & & & & & & & \\
\hline galangal & $\mathrm{x}$ & & & & & $\mathrm{x}$ & & & $\mathrm{x}$ & & & & & & & $\mathrm{x}$ & & & & & & & & \\
\hline galangal & $x$ & & & & & $\mathrm{x}$ & & & $\mathrm{x}$ & & & & & & & & $\mathrm{x}$ & & & & & & & \\
\hline galangal & $\mathrm{x}$ & & & & & $\mathrm{x}$ & & & $\mathrm{x}$ & & & & & & & & & & & $\mathrm{x}$ & & & & \\
\hline galangal & $\mathrm{x}$ & & & & & $\mathrm{x}$ & & & $\mathrm{x}$ & & & & & & & & & & & & & $\mathrm{x}$ & & \\
\hline galangal & $\mathrm{x}$ & & & & & $\mathrm{x}$ & & & $\mathrm{x}$ & & & & & & & & & & & & & & $\mathrm{x}$ & \\
\hline galangal & $\mathrm{x}$ & & & & & $\mathrm{x}$ & & & $\mathrm{x}$ & & & & & & & & & & & & & & & $\mathrm{x}$ \\
\hline
\end{tabular}

Figure 5. Shows recommendation rule for galangal

\section{CONCLUSION}

Research has presented the process of knowledge integrated with data management to achieve knowledge modeling as the concept of intercropping in rubber plantations to create an Intercropping Ontology for a DSS aware rules for recommending the type and list of plants suitable for the area of each farmer. Using criteria of the decision including; rubber age, the spacing between rows, soil condition, and the water resources used in agriculture. The integrated dataset developed was analyzed and grouped data from existing sources of government and related agencies. The knowledge-base contains a knowledge domain development process using ontology method as a knowledge acquisition from the experts to find the concept, rules, and data relationships. Which is designed to have a Triangular method to validate the accuracy and consistency of the data.

In addition, the research also found the decision criteria for intercropping from [26]. It was studied by using environmental factors consisting of soil conditions, cost, and revenue. It adds up to 3 more factors: 1) distance between rows of rubber plantation farmmer, which affects the planning of rubber plantation because this phase affects sunlight and disturbs the growth of the main crop. 2) The age criteria of rubber due to different age tree saffecting different shades in the rubber plantations, and 3) water factor for agriculture of each farmer. This factor is directly related to different types of plants. For example, growing bananas in the rubber plantations requires water to be used all year. However, upland rice growing relies only on seasonal rain, etc. 
The results of this research process help the researcher understand the concept and rules for selecting a suitable plant. Can be used to create the correct and appropriate Intercropping Ontology for DSS to suggest more suitable and precise plants for individual farmers' areas. The next step in the research is to develop the Intercropping Ontology by using ontology editor, a database and rule to ontology mapping process, and evaluation.

\section{ACKNOWLEDGEMENTS}

Thanks are given to the Rubber Authority of Thailand Nakhon Si Thammarat Office, Land Development Regional Office 11 Suratthani, Vegetables and Fruit Central Market, Nakhon Si Thammarat Agricultural Office informative and coordinative experts in rubber plantation for research data. Special thanks to the experts who took time to be interviewed, focus group and visit the rubber plantation to inspect the results and validation. Last but not least, thank you to Rajamangala University of Technology Srivijaya Thailand who sponsored the research scholarship.

\section{REFERENCES}

[1] Office of Agricultural Economics, "Agricultura. Statistics of Thailand 2015," Office of Agricultural Economic," Ministry of Agriculture and Cooperatives Thailand, 2015.

[2] Bank of Thailand, "Report on Major Agricultural Price Trends in Southern Thailand," Bank of Thailand, 2016.

[3] K. Phoksawat, M. Mahmuddin, "Ontology-based knowledge and optimization model for Decision Support System to intercropping," 2016 International Computer Science and Engineering Conference (ICSEC), pp. 1-6, 2016.

[4] S. R. Mousavi and H. Eskandari, "A general overview on intercropping and its advantages in sustainable agriculture," Journal of Applied Environmental and Biological Sciences, vol. 1, pp. 482-486, 2011.

[5] M. A. Boudreau, "Diseases in intercropping systems," Annual review of phytopathology, vol. 51, pp. 499-519, 2013.

[6] Office of the National Economic and Social Development Board, "The 11th National Economic and Social Development Plan,” 2016.

[7] R. Jingjit, "Insights "Smart Farmer" just a new concept. Or reinvent agriculture Thailand," Trade Policy and Stratege Office, Mistry of Commerce Thailand, 2015.

[8] E. P. Purwandari, et al., "Online Expert Systems for Bamboo Identification Using Case Based Reasoning," International Journal of Electrical \& Computer Engineering (IJECE), vol. 7(5), pp. 2766-2772, 2017.

[9] J. K. Tarus, et al., "Knowledge-based recommendation: a review of ontology-based recommender systems for e-learning," Artificial intelligence review, vol. 50, pp. 21-48, 2018.

[10] T. B. Lee, et al., "The semantic web," Scientific american, vol. 284, pp. 28-37, 2001.

[11] T. Slimani, "Ontology development: A comparing study on tools, languages and formalisms," Indian Journal of Science and Technology, vol. 8, 2015.

[12] T. R. Gruber, "A translation approach to portable ontology specifications," Knowledge acquisition, vol. 5, pp. 199-220, 1993.

[13] R. Gunawan, K. Mustofa, "Finding Knowledge from Indonesian Traditional Medicine using Semantic Web Rule Language," International Journal of Electrical \& Computer Engineering (IJECE), vol. 7(6), pp. 3674-3682, 2017.

[14] R. Sulthana and S. Ramasamy, "Context based classification of reviews using association rule mining, fuzzy logics and ontology," Bulletin of Electrical Engineering and Informatics (BEEI), vol. 6, pp. 250-255, 2017.

[15] F. Antunes, et al., "Semantic web and decision support systems," Journal of Decision Systems, vol. 25, pp. 79-93, 2016.

[16] N. F. Noy and D. L. McGuinness, “Ontology development 101: A guide to creating your first ontology," Stanford knowledge systems laboratory technical report KSL-01-05 and Stanford medical informatics technical report SMI2001-0880, Stanford, CA, 2001.

[17] N. Kaewboonma, et al., "Ontology development for drought management information," International Journal of Metadata, Semantics and Ontologies, vol. 9, pp. 324-332, 2014.

[18] F. Yue, et al., "A Decision Support System Framework for Scheme Design of Motor System Energy-Saving," Information Science and Control Engineering (ICISCE), 2015 2nd International Conference on, pp. 537-541, 2015.

[19] B. C. Jantzen, et al., Ontology \& methodology, Springer, 2015.

[20] T. Supnithi, et al., "Ontology Based Orchid Knowledge Platform for Knowledge Services in Orchid Cluster," 2011 Annual SRII Global Conference, 2011, pp. 540-549.

[21] N. G. Fielding, "Triangulation and mixed methods designs: Data integration with new research technologies," Journal of Mixed Methods Research, vol. 6, pp. 124-136, 2012.

[22] C. Thierfelder, et al., "A comparative analysis of conservation agriculture systems: Benefits and challenges of rotations and intercropping in Zimbabwe," Field crops research, vol. 137, pp. 237-250, 2012.

[23] Office of Soil Resources Survey and Research, "Soil Survey Report of Nakhon Si Thammarat province," Suratanee: Land Development Department, Ministry of Agriculture and Cooperatives, pp. 57, 2010.

[24] Department of Agriculture Extension, "Alternatives way for small para-rubber farmers as supplemented revenue," 2014. 
[25] I. Horrocks, et al., "SWRL: A semantic web rule language combining OWL and RuleML," W3C Member submission, vol. 21, pp. 79, 2004.

[26] C. Srisawat and J. Payakpate, "Comparison of MCDM Methods for Intercrop Selection in Rubber Plantatios," Journal of Information and Communication Technology, vol. 15, pp. 165-182, 2016.

\section{BIOGRAPHIES OF AUTHORS}
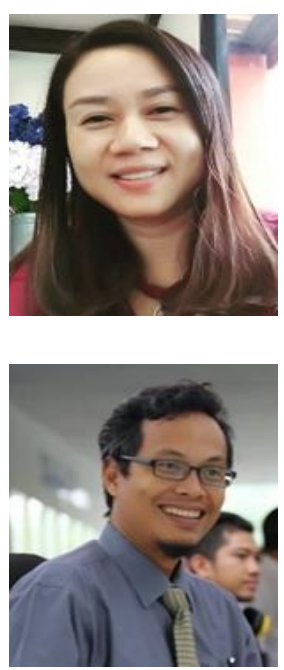

Asst. Prof. Kornkanok Phoksawat Ph.D. candidate in Information Technology at School of Computing, Universiti Utara Malaysia (UUM) and also is Assistant Professor of Information System, Faculty of Management Technology Rajamangala University of Technology Srivijaya Nakhon Si Thammarat Campus, Thailand. She has expertise in Management Information System and Knowledge-Based System. She is a reviewer of Management Science Journal, Suratthni Rajabhat University Thailand.

Dr. Massudi Mahmuddin obtained his $\mathrm{PhD}$ in 2008 in the areas of system engineering, Cardiff University, United Kingdom. He is currently a senior lecturer with the Department of Computer Science, School of Computing, Universiti Utara Malaysia (UUM). During last 18 years of his stay at the school, his teaching, research and development interests have been towards of technical and social aspect of computing, computational intelligent and expert system. Currently he is Director of Student Affairs UUM. He is also member for Malaysian Statistic Association, Internet Society, chairperson for P2A Malaysian Chapter (an association of students mobilities in ASEAN countries), and coordinator for School-UUM Cluster of excellent under Ministry of Education. In UUM, besides serving as examiner for Master and $\mathrm{PhD}$ theses, he is also a Senate member. He is also regularly invited as an external examiner for Master and Ph.D. theses from other universities including Universiti Teknologi Malaysia (UTM), Universiti Kebangsaan Malaysia (UKM), Universiti Malaysia Sarawak (Unimas), and Asean e-University (AEU). He also reviewer for many conference and journal including The Security and Communication Networks, Neural Computing and Application, The International Journal of Computer Science and Information Technology for Education, Human Centric Computing and Information Sciences, and Malaysian Journal of Computer Sciences. 